\title{
Fuel selection in white adipose tissue
}

\author{
BY KEITH N. FRAYN, SANDY M. HUMPHREYS AND \\ SIMON W. COPPACK* \\ Oxford Lipid Metabolism Group, Nuffield Department of Clinical Medicine, Radcliffe Infirmary, \\ Oxford $O X 26 H E$
}

\section{Sélection de substrats énergétiques dans le tissu adipeux blanc}

\begin{abstract}
RÉSUMÉ
Lavoisier a conclu que 'la respiration est donc une combustion'. Si ce concept est parfaitement valable pour un animal entier, il ne peut s'appliquer totalement au niveau du tissu. Le tissu adipeux blanc a un taux de consommation d' $\mathrm{O}_{2}$ très faible, mais ceci n'implique pas que son activité métabolique est faible. En fait, c'est un tissu hautement spécialisé qui s'est développé pour réguler le flux de grandes quantités de substrats lipidiques, tout en consommant lui-même fort peu d'énergie. Les faibles besoins énergétiques du tissu adipeux blanc semblent être largement satisfaits par l'utilisation du glucose, en partie en anaérobie, et en partie en aérobie. L'absorption du glucose se fait par l'intermédiaire du GLUT-4, le transporteur du glucose régulé par l'insuline, avec un composant 'basal' plus petit par l'intermédiaire du GLUT-1. L'absorption de glucose est sensible à l'insuline in vitro, mais peut l'être moins in vivo, peut-être parce qu'il est déjà stimulé presque au maximum à des concentrations d'insuline physiologiques. Il est possible également que le tissu adipeux blanc oxyde les acides aminés à chaîne ramifiée. D'autres substrats énergétiques hydrosolubles comme les corps cétoniques et l'acétate sont extraits du sang par le tissu adipeux blanc, bien qu'on ignore ce qu'ils deviennent. Le tissu adipeux blanc est l'ultime réservoir d'énergie chimique dans le corps. En tant que tel, ce tissu doit réguler le stockage net ou la perte de triacylglycérol (TAG) pour répondre quantitativement au déséquilibre intégré entre l'absorption et la dépense d'énergie (du corps tout entier) sur des périodes qui dépassent quelques jours. On connaît mieux maintenant les caractéristiques subtiles de la régulation métabolique dans le tissu adipeux blanc par lesquelles ceci se produit. Le tissu adipeux blanc régule le flux des substrats lipidiques essentiellement en modulant l'activité de deux enzymes, la lipase hormono-sensible ( $E C$ 3.1.1.3; LHS), et la lipase lipoprotéinique (EC 3.1.1.34; LLP). Le processus d'estérification des acides gras est également régulé bien qu'on ne soit pas certain du site exact de cette régulation. La LHS et la LLP sont régulées de manière réciproque. Dans les situations aiguës d'alimentation et de jeûne entre les repas, cette régulation semble être effectuée essentiellement par des modifications dans la concentration d'insuline plasmatique. (Dans des situations 'de stress' telles que l'exercice physique, c'est le système sympatho-adrénalique qui joue le rôle principal dans la mobilisation des graisses.) Après le jeûne de la nuit, la LHS est active alors que la LLP l'est moins. Les acides gras libérés par l'action de la LHS sur le TAG intra-cellulaire

\footnotetext{
* Present address: Academic Division of Medicine, University College London Medical School, Archway Wing, Whittington Hospital, London N19 3UA.
} 
afflue dans les capillaires, et entre ainsi dans le plasma systémique. Après un repas, l'activité de la LHS est supprimée (et l'estérification augmentée), alors que l'activité de la LLP augmente. Les acides gras libérés par l'action de la LLP sur le TAG circulant (le TAG des chylomicrons en particulier) vont des capillaires aux adipocytes où ils sont estérifiés en vue de leur stockage sous forme de TAG. Les acides gras libérés par l'action de la LLP sur le TAG circulant ne sont pas tous stockés dans le tissu; ils semblent plutôt suivre la direction du 'flux de masse' des acides gras (Frayn et al. 1994). A l'état de jeûne nocturne, par exemple, où la LLP agit essentiellement sur le TAG des lipoprotéines de très faible densité, les acides gras produits sont presque tous libérés dans la circulation. A l'état post-prandial, où la LLP est la plus active, une certaine proportion des acide gras qu'elle libère (jusqu'à $75 \%$ après un repas riche en graisse) sont également libérés dans le plasma. Ainsi, la LLP intervient dans l'apport des acides gras à partir du tissu adipeux blanc. L'importance de l'action de la LLP (dans les situations aiguës) a moins tendance à se modifier que celle de la LHS. On peut considérer que la LLP génère un fonds d'acides gras extra-cellulaires, dont l'utilisation est déterminé par des évènements intracellulaires: à l'état post-prandial, la suppression de l'activité de la LHS (et la stimulation de l'estérification) conduit à un gradient de concentration de l'espace extra-cellulaire vers l'espace intra-cellulaire qui attire les acides gras pour les stocker sous forme de TAG. Ainsi, la modification de l'activité de la LHS joue un rôle essentiel dans la régulation de la mobilisation des graisses aussi bien que de leur stockage. Le rôle important du tissu adipeux blanc dans la régulation du flux des substrats énergétiques lipidiques est donc produit par la régulation coordonnée de ces deux enzymes. Le tissu adipeux blanc est plus qu'un lieu de stockage pour les graisses en excédent. C'est un tissu très important aussi bien pour le biochimiste qui s'intéresse à la régulation du métabolisme, que pour le nutritionniste désireux de comprendre comment le poids du corps est régulé.

Nous remercions tous le membres de l'Oxford Lipid Metabolism Group qui ont collaboré à nos travaux sur le métabolisme du tissu adipeux blanc au cours de ces dernières années.

Antoine Lavoisier (1743-1794) concluded that 'la respiration est donc une combustion'. This is clearly true for a whole animal, as he intended it to be understood. But the measurement of $\mathrm{O}_{2}$ consumption as an estimate of metabolic rate in an individual tissue may give a very misleading view of its metabolic activity. Table 1 shows the contribution of different organs and tissues to $\mathrm{O}_{2}$ consumption in the whole body. The role of white adipose tissue, with its low rate of $\mathrm{O}_{2}$ consumption (whether expressed per unit wet weight, or even per unit cell water), is very minor even though white adipose tissue may amount to $20-30 \%$ of normal body weight. Does this mean that adipose tissue is a metabolically-inactive tissue? In the present review, the argument will be presented that, on the contrary, adipose tissue is an extremely active tissue metabolically. However, its role is not to consume energy-providing substrates so much as to regulate the flow of energy-providing substrates. In fact, judged against the standards of other tissues such as skeletal muscle, it is a supremely efficient tissue in terms of the small amount of energy it consumes, in relation to the large flow of energy which it regulates. 
Table 1. Oxygen consumption by different organs*

\begin{tabular}{lcccc}
\hline & & \multicolumn{3}{c}{$\mathrm{O}_{2}$ consumption (ml/min) } \\
\cline { 3 - 5 } Tissue or organ & Wet wt $(\mathrm{kg})$ & $\begin{array}{c}\text { per } \mathrm{kg} \\
\text { wet wt }\end{array}$ & $\begin{array}{c}\text { per litre } \\
\text { tissue water }\end{array}$ & $\begin{array}{c}\text { in the whole } \\
\text { body }\end{array}$ \\
\hline Liver & $1 \cdot 7$ & 44 & 60 & 75 \\
Skeletal muscle (resting) & $20-30$ & $2 \cdot 8$ & 4 & 70 \\
Gastrointestinal tract & $2 \cdot 6$ & 22 & 30 & 58 \\
Brain & $1 \cdot 5$ & 31 & 40 & 46 \\
Heart & $0 \cdot 3$ & 90 & 120 & 27 \\
White adipose tissue & $10-20$ & $0 \cdot 3$ & 3 & $4 \cdot 5$ \\
\hline
\end{tabular}

* Reproduced from Frayn (1992) with permission from Raven Press Ltd, and based on references given therein. The value for white adipose tissue has been slightly revised. Different approaches suggest a larger contribution from adipose tissue to whole-body $\mathrm{O}_{2}$ consumption (Elia, 1992).

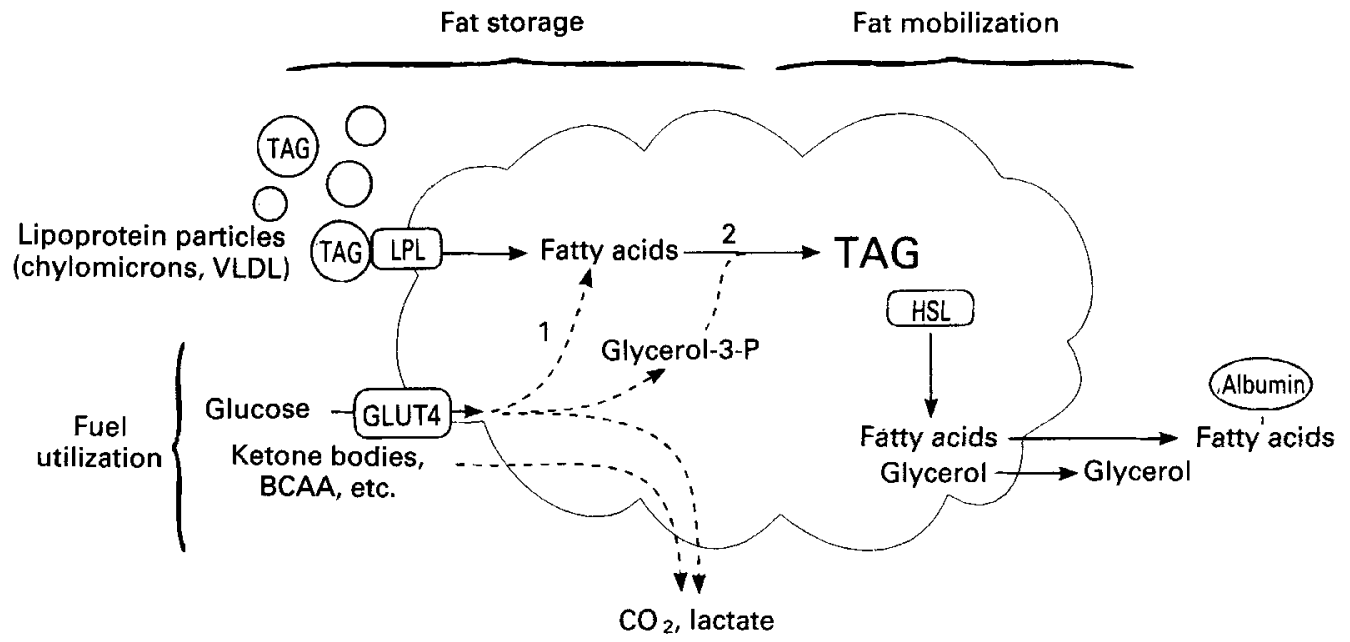

Fig. 1. Major routes of fuel metabolism in white adipose tissue. A distinction is made between fuel utilization and the routes of fat storage and fat mobilization. Pathways are (1) de novo lipogenesis (not quantitatively important in human white adipose tissue), (2) the phosphatidic acid pathway of fatty acid esterification. BCAA, branched-chain amino acids; TAG, triacylglycerol; HSL, hormone-sensitive lipase (EC 3.1.1.3); LPL, lipoprotein lipase ( $E C$ 3.1.1.34); GLUT4, insulin-regulated glucose transporter.

Thus, the concept of 'fuel selection' by white adipose tissue is somewhat misleading in terms of this tissue's major metabolic function, if fuel selection is taken to mean fuel consumption. Rather, fuel selection in white adipose tissue must be viewed in terms of the tissue's regulation of fuel storage and release. Here, a brief discussion of the major fuels consumed by adipose tissue will be followed by a description of its more important role in the regulation of substrate flow. There are some important species differences, and data from human white adipose tissue will be presented wherever possible.

A summary of the major routes of fuel metabolism in white adipose tissue is given in Fig. 1. 


\section{METABOLIC FUELS FOR WHITE ADIPOSE TISSUE}

\section{Glucose}

The energy required by white adipose tissue for regulatory and biosynthetic purposes appears to be obtained primarily from glucose catabolism. A number of measurements of the RQ of white adipose tissue in vitro bear out the idea that glucose is the major oxidative fuel (RQ 1.0), although lower values of RQ are observed if no glucose is supplied (for review, see Frayn, 1992). In vitro, a large percentage (up to 50\%) of the glucose consumed by white adipose tissue is released as lactate (Mårin et al. 1987). Measurements in vivo, however, suggest a much smaller percentage of anaerobic glycolysis, with about $20 \%$ of the glucose consumed released as lactate (Frayn et al. 1989, 1993a).

White adipose tissue expresses the insulin-regulated glucose transporter GLUT4 as well as the non-insulin-regulated transporter GLUT1, which may provide its basal glucose requirements (Pedersen et al. 1992). Not surprisingly, therefore, glucose uptake by white adipose tissue is stimulated by insulin in vitro. However, whilst this can be demonstrated in vivo (Coppack et al. 1989a), the response to insulin is not very marked, and in some studies glucose uptake from plasma by white adipose tissue appears to be regulated more by the prevailing glucose concentration (perhaps reflecting GLUT1 activity) than by the insulin concentration (Coppack et al. 1989b). In subjects given a high-fat, high-carbohydrate meal, glucose uptake by white adipose tissue increased in the postprandial period, but it was not further increased by infusion of insulin in high concentrations (Frayn et al. 1994). A possible explanation for the lack of a large effect of insulin on glucose uptake by white adipose tissue in vivo may lie in the exquisite sensitivity to insulin of white adipose tissue glucose uptake seen in some preparations in vitro: the concentration for half-maximal stimulation may be as low as $13 \mathrm{pmol} / \mathrm{l}$ (2 munits/l; Taylor et al. 1984). If this were true in vivo, then glucose uptake would be maximally insulin-stimulated at low physiological insulin concentrations.

Despite the ability of white adipose tissue to take up and oxidize glucose, it is generally accepted that this plays little part in whole-body glucose homeostasis. In humans, the removal of glucose by white adipose tissue following an oral glucose load has been estimated by different approaches to amount to about $4 \%$ of the load (Marrin et al. 1987; Coppack et al. $1990 a$ ).

\section{Fatty acids}

Despite the abundance of fatty acids in white adipose tissue, it seems probable that they do not form an important metabolic fuel for the tissue. In rat white adipose tissue, oxidation of fatty acids is a very minor route compared with esterification (Harper \& Saggerson, 1976). In humans, there are no conclusive data on the oxidation of fatty acids. Some measurements of $\mathrm{O}_{2}$ consumption of human white adipose tissue in vivo show that glucose extracted from plasma cannot account for all the $\mathrm{O}_{2}$ consumption (Coppack et al. 1990b) but the difference might be accounted for in part by breakdown of the small local glycogen store during the post-absorptive period (Rigden et al. 1990).

\section{Amino acids}

The pattern of amino acid metabolism in white adipose tissue appears to be similar to that in skeletal muscle. White adipose tissue releases both alanine and glutamine, in vitro 
(Snell \& Duff, 1977; Tischler \& Goldberg, 1980) and in vivo (Frayn et al. 1991; Kowalski \& Watford, 1994), and extracts glutamate from the blood (Frayn et al. 1991; Kowalski \& Watford, 1994). In rat adipose tissue in vitro, branched-chain amino acids are oxidized and may also be used as substrates for lipid synthesis (for review, see Frayn et al. 1991), but their quantitative significance as metabolic fuels in white adipose tissue in vivo is not clear.

\section{Ketone bodies and other fuels}

Both acetoacetate and 3-hydroxybutyrate are extracted from blood by white adipose tissue in vivo in proportion to their concentration (Coppack \& Miles, 1992; Frayn et al. $1993 b$ ). Their fate, however, is unknown. Acetate is also extracted in the post-absorptive state (Coppack et al. 1990b) but, even if all oxidized, could contribute only a small proportion of the $\mathrm{O}_{2}$ consumption. Its extraction cannot easily be measured in vivo under conditions when its concentration is elevated (e.g. after ethanol ingestion; Frayn et al. 1990).

\section{REGULATION OF FUEL MOVEMENT IN WHITE ADIPOSE TISSUE}

Adipose tissue undoubtedly has many specialized roles. For instance, it is a source of at least one, and possibly two, components of the complement cascade (Baldo et al. 1993; Napolitano et al. 1994). It is a producer of prostaglandins (Richelsen, 1992) which may be local regulators of blood flow and metabolism. It is an important site of interconversion of steroid hormones (Siiteri, 1987; Boulton et al. 1992), and an important site of oestrogen production in post-menopausal women, probably explaining the protection of obese women from osteoporosis (Dawson-Hughes et al. 1987).

However, it is clear that the major role for which white adipose tissue is specialized is that of the storage and release of chemical energy in the form of fatty acids and triacylglycerol. In addition, we suggest that white adipose tissue 'directs' the flow of large quantities of fatty acids from circulating triacylglycerol (TAG) without their actually entering the adipocytes. An overview of these roles of adipose tissue is given in Fig. 1.

The direction of 'energy flow' between white adipose tissue and the bloodstream, whether primarily into the tissue, for storage, or out of the tissue into the circulation, may change rapidly. For instance, a state of fat mobilization (net outward flow of fatty acids) changes rapidly to one of fat deposition (net inward flow of fatty acids) after ingestion of the first meal of the day. The rate of release of stored energy (fat mobilization) may increase dramatically in states such as exercise or 'stress' (e.g. hypoglycaemia). The control of these processes requires energy, and this is reflected in the consumption by white adipose tissue of the metabolic fuels discussed previously.

\section{Fat mobilization in the post-absorptive state}

The post-absorptive state will be taken to be that after overnight fast in humans. In this state, the net flow of fatty acids is outwards across the adipose tissue capillary wall, into the circulation. This state is brought about by activation, during overnight fast, of the intracellular enzyme hormone-sensitive lipase ( $E C$ 3.1.1.3; HSL) which acts on the stored TAG to release non-esterified fatty acids (NEFA) and glycerol. (HSL catalyses 
removal of the first two fatty acids from each molecule of TAG: the third is removed mainly by a very active monoacylglycerol lipase (EC 3.1.1.23; Belfrage et al. 1985).)

Short-term changes in the activity of HSL appear to be brought about mainly by changes in its phosphorylation state (for detailed review, see Lafontan \& Langin, 1995). The factors which lead to its activation during an overnight fast are not clear. The major factor may be the progressive removal of suppression by insulin, as insulin concentrations fall with fasting. The role of glucagon in regulation of fat mobilization in humans is controversial (Wu et al. 1990; Jensen et al. 1991; Carlson et al. 1993) but on balance appears minor. Studies in humans by microdialysis of subcutaneous white adipose tissue imply that the net adrenergic effect is inhibitory rather than stimulatory after overnight fast (Arner et al. 1990). (Adrenergic influences undoubtedly become important during more rapid activation of fat mobilization, e.g. during exercise (Arner et al. 1990).) Hormonal regulation of lipolysis has recently been reviewed in detail (Coppack et al. 1994).

Of the fatty acids released in lipolysis, some are re-esterified without leaving the tissue. In human white adipose tissue in vivo after overnight fast, about $10-20 \%$ of fatty acids are re-esterified (Coppack et al. 1990b; Frayn, 1992), although rather larger values are observed in vitro (e.g. about $40 \%$; Hammond \& Johnston, 1987). It has been suggested that these fatty acids take an extracellular route (Edens et al. 1990). The fatty acids released probably leave the adipocyte by a carrier-mediated process (Abumrad et al. 1984; Harmon et al. 1992) and diffuse, perhaps by some structured pathway, to the capillaries.

Although there is usually no significant dietary TAG present in the circulation in the form of chylomicron TAG after overnight fast, the enzyme lipoprotein lipase ( $E C$ 3.1.1.34; LPL) in white adipose tissue is not completely inactive. About $10 \%$ of plasma TAG is extracted during a single passage through adipose tissue in this state in normal subjects (although variable between subjects; Potts et al. 1991). This reflects mainly removal of TAG from the VLDL fraction (Potts et al. 1991). The fate of the fatty acids released by LPL action is of interest. In principle there may be a bi-directional flow of fatty acids between adipocytes and capillaries, with uptake and esterification of LPL-derived fatty acids. However, there is no known mechanism by which this could be brought about, and instead it seems more likely that fatty acids flow between cells and capillaries along concentration gradients. Thus, in this state it is most likely that virtually all the LPL-derived fatty acids will be released into the venous plasma (see p. 184). (The assumption that they behave similarly to HSL-derived fatty acids, i.e. that $90 \%$ leave in the venous plasma in this state, gives consistently plausible results in experiments in vivo (Frayn et al. 1994).) Thus, the role of white adipose tissue LPL in the overnight-fasted state may be the hydrolysis of circulating VLDL-TAG in order that its fatty acids can be utilized by tissues such as skeletal muscle, in which LPL is much less active with VLDL-TAG as a substrate (Potts et al. 1991).

\section{Fat storage in the postprandial state}

HSL activity is rapidly suppressed after a meal (Coppack et al. 1992), presumably through the rise in circulating insulin concentration (Fig. 2). Fat mobilization is very sensitive to insulin in vivo, with concentrations of about $120 \mathrm{pmol} / 1$ ( 20 munits/l) or less giving half-maximal suppression (Jensen et al. 1989; Bonadonna et al. 1990). After a 


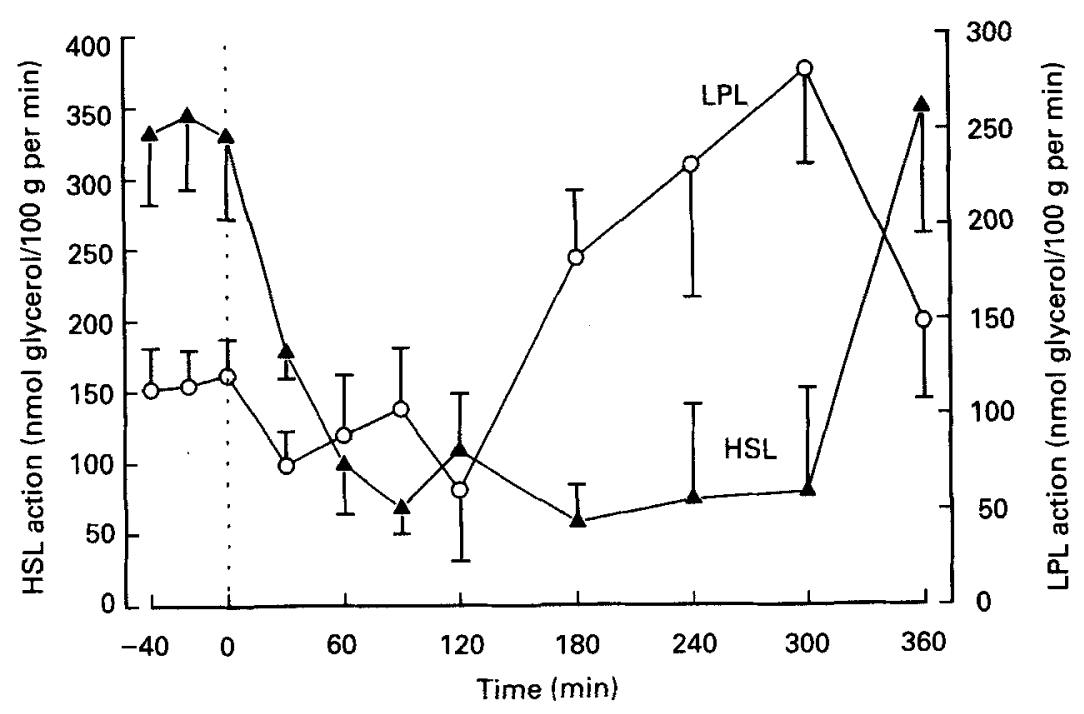

Fig. 2. Rates of action of hormone-sensitive lipase (EC 3.1.1.3; HSL; $\mathbf{A})$ and lipoprotein lipase (EC 3.1.1.34; LPL; $O)$ in white adipose tissue in vivo after overnight fast $(-40-0 \mathrm{~min})$, and after eating a mixed meal $(3 \cdot 1$ MJ, $41 \%$ energy from fat), in thirteen normal subjects. Details of the studies and methods of calculation were given by Coppack et al. (1992); the present data (mean values with their standard errors represented by vertical bars) include three additional subjects.

normal meal, the insulin concentration rises above this level within 30 min and may remain above this level for several hours (Coppack et al. 1992) and, thus, fat mobilization will remain suppressed.

In contrast, the rate of action of LPL in white adipose tissue is increased after a meal (Fig. 2). There appear to be a number of factors which bring this about. It is activated directly by insulin over a matter of hours (Sadur \& Eckel, 1982); this activation occurs at a number of stages, i.e. increased transcription, altered intracellular processing and possibly increased export to the capillary lumen (Eckel, 1989; Ong \& Kern, 1989). In addition, there is a change in the substrate mixture available to the enzyme. TAG-rich chylomicrons enter the circulation, and these are the preferred substrate (above VLDL) for LPL in white adipose tissue.

For the fatty acids released by LPL action to be stored within white adipose tissue, they must be esterified. The predominant route of fatty acid esterification in white adipose tissue is the phosphatidic acid pathway, in which glycerol-3-phosphate accepts sequentially three acyl groups in the form of their CoA esters. It has long been known that insulin stimulates esterification of fatty acids in white adipose tissue (Leboeuf, 1965) and this occurs in part through increased glucose uptake and provision of glycerol-3phosphate (via glycolysis). However, there is evidence for a more direct effect of insulin in vivo (Frayn et al. 1994), and also evidence for a peptide factor (acylation-stimulating protein), released after meals and possibly synthesized by adipocytes, which may stimulate esterification (Sniderman et al. 1992; Baldo et al. 1993). Increased esterification of fatty acids also serves to entrap any fatty acids generated intracellularly via residual HSL activity (Coppack et al. 1989a).

Thus, in the postprandial state, fatty acids generated by increased LPL action are 

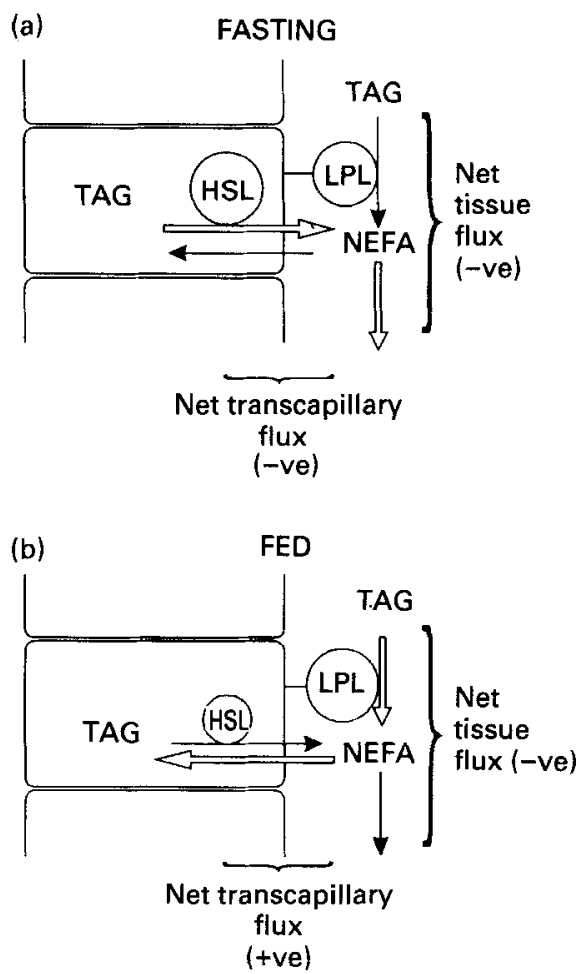

Fig. 3. Schematic view of the movement of fatty acids in white adipose tissue in the post-absorptive (a) and postprandial (b) states. Lipoprotein lipase (EC 3.1.1.34; LPL) acts on circulating triacylglycerol (TAG), and hormone-sensitive lipase (EC 3.1.1.3; HSL) on intracellular TAG, to release fatty acids which are shown forming a common extracellular pool (probably not intravascular). In both states, there is a net efflux of fatty acids from the tissue (shown as net tissue flux). The net flux of fatty acids between adipocytes and capillaries is shown as net transcapillary flux: this will be negative (-ve; net outward flow, fat mobilization) in the fasting state and positive (+ve; net inward flow, fat deposition) in the fed state. NEFA, non-esterified fatty acids.

apparently drawn into white adipose tissue, down a concentration gradient produced by suppression of intracellular lipolysis (HSL action) and stimulation of fatty acid esterification. The net flow of fatty acids across the adipose tissue capillary wall changes from outward (in the overnight-fasted state) to inward (Figs. 3 and 4), and the body begins to 'lay down fat'. Nevertheless, a considerable proportion of the fatty acids released from circulating TAG by LPL action escape entrapment in the tissue and are released into the venous plasma (Fig. 5).

HSL is usually thought of as the enzyme responsible for fat mobilization, and LPL as the enzyme bringing about fat storage. However, what is important is undoubtedly the coordinated regulation of these two enzymes. Suppression of HSL activity is at least as important as activation of LPL in bringing about net fat deposition after a meal; in fact, in our studies of the post-absorptive to postprandial transition, we find that HSL activity changes through a greater range than does that of LPL (Coppack et al. 1992; Frayn et al. 1994). It could be argued, therefore, that LPL activity is relatively constant (during normal daily life), and that modulation of the activity of HSL (together with regulation of fatty acid esterification) regulates the flow of fatty acids in or out of white adipose tissue. LPL generates a relatively constant pool of fatty acids somewhere in the extra- 
(a)

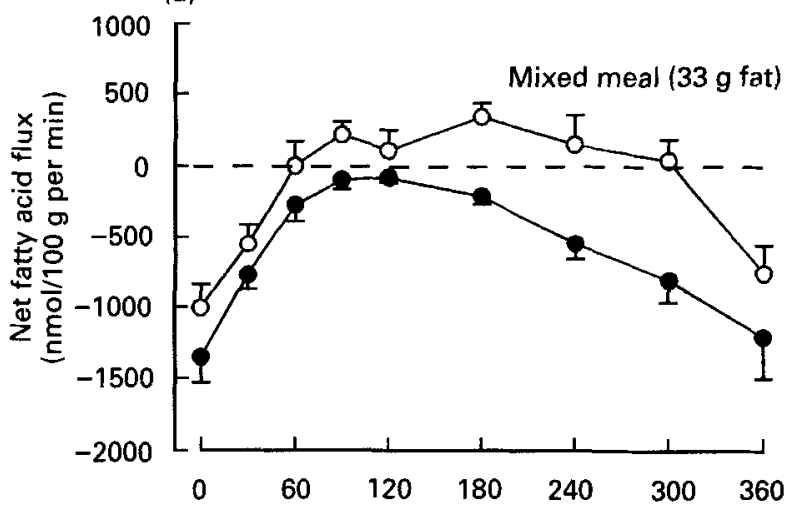

(b)

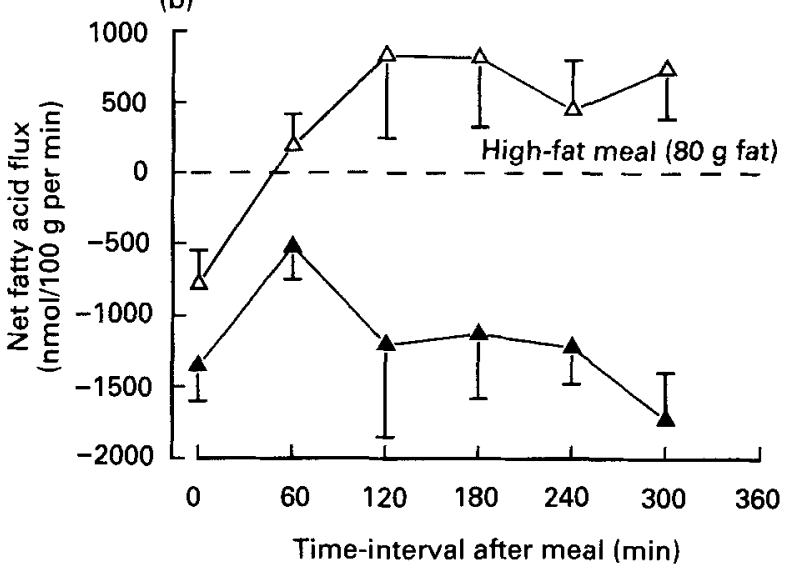

Fig. 4. Net fluxes of fatty acids in subcutaneous white adipose tissue in vivo in normal subjects, in the post-absorptive state (mean values given at time 0 ) and after a meal. $(O, \Delta)$, Net transcapillary flux (net flux of fatty acids between adipocytes and capillaries); $(\mathbf{O}, \mathbf{\Lambda})$, net tissue efflux (net efflux of fatty acids from the tissue always negative). (a) Mean values with their standard errors represented by vertical bars for thirteen normal subjects before and after a mixed meal ( $3.1 \mathrm{MJ}, 33 \mathrm{~g}$ fat); (b) mean values with their standard errors represented by vertical bars for six normal subjects before and after a high-fat meal $(4.7 \mathrm{MJ}, 80 \mathrm{~g}$ fat $)$. Values are absolute rates (adjusted for blood flow) calculated as described by Frayn et al. (1994). Mixed meal, data from Coppack et al. (1992) with additional studies (Frayn, Humphreys and Coppack, unpublished results); high-fat meal, data from Frayn et al. (1994).

cellular environment; the fate of these fatty acids (uptake into the tissue $v$. loss into the plasma) is determined by intracellular events.

This view of the regulation of fatty acid movement in white adipose tissue also helps to shed light on a problem discussed previously (Frayn et al. 1992). Over any reasonably long time, the amount of TAG stored in, or lost from, white adipose tissue is closely matched with the imbalance between energy intake and energy expenditure in the whole body. Precisely what regulatory processes, at the level of adipose tissue, are able to respond to the excess or deficiency of various nutrients in the plasma? We can now see that the balance between net fatty acid release and net fatty acid uptake is controlled by a number of factors, including the plasma insulin concentration (via modulation of HSL, 


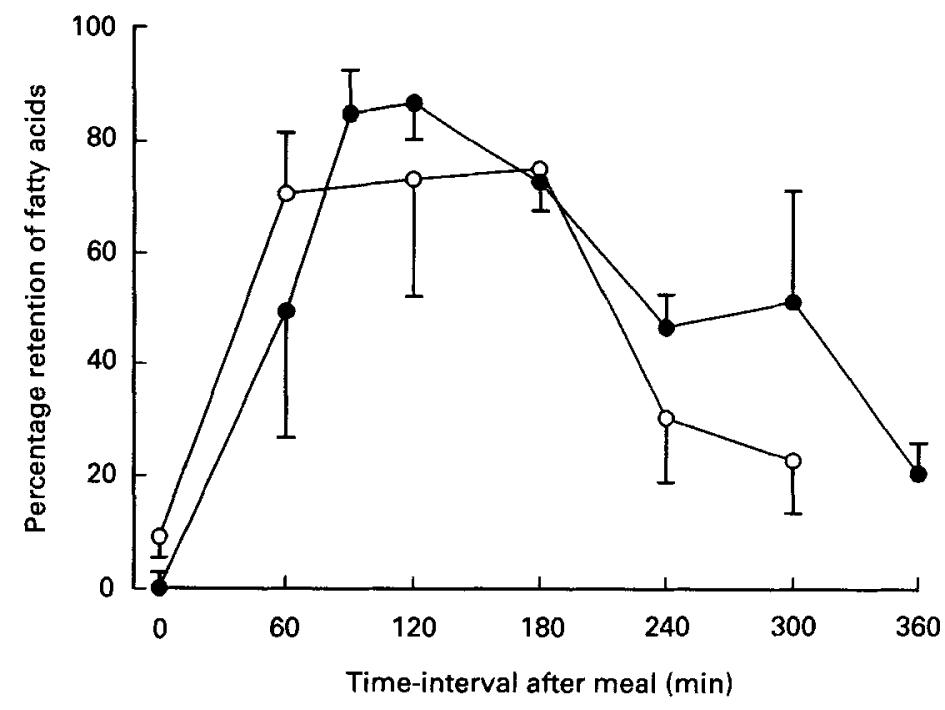

Fig. 5. Percentage retention in white adipose tissue in vivo of the fatty acids released by lipoprotein lipase (EC 3.1.1.34; LPL) action on circulating triacylglycerol. The values are calculated on the assumption of equal re-esterification of fatty acids derived from hormone-sensitive lipase (EC 3.1.1.3) and from LPL action, as discussed in Frayn et al. (1994). Results are shown for normal subjects, before (time 0) and after eating a meal: $(\mathrm{O})$, a mixed meal providing $3.1 \mathrm{MJ}$ with $33 \mathrm{~g}$ fat $(n 13)$; (O), a high-fat meal providing $4.7 \mathrm{MJ}$ with $80 \mathrm{~g}$ fat (n 6). Mixed meal data from Coppack et al. (1992) with additional studies (Frayn, Humphreys and Coppack, unpublished results); high-fat meal data from Frayn et al. (1994).

LPL and esterification), the plasma glucose concentration (via modulation of HSL; Carlson et al. 1991), and the plasma TAG concentration (through its mass action effect on LPL action). Of course, there may be many other factors (e.g. gastrointestinal hormones or adipocyte-derived peptides; Sniderman et al. 1992) whose role is as yet not known. What is clear is that the precise regulation of fat storage and mobilization in relation to energy balance is so important to life that white adipose tissue has evolved as a supremely responsive site of metabolic regulation.

\section{ENERGETICS OF REGULATION OF FAT STORAGE AND MOBILIZATION}

The process of hydrolysis of ester bonds by a lipase does not require energy. Therefore, adipose tissue may convert circulating TAG (e.g. in VLDL) to circulating NEFA with no energetic cost, other than that of synthesis and turnover of the enzyme LPL. There is a small energetic cost to the storage of intracellular TAG from circulating TAG. After uptake of the fatty acids, they must be activated to form their CoA esters; this uses two ATP (i.e. six per molecule TAG). White adipose tissue lacks significant glycerol kinase (EC 2.7.1.30), so glycerol-3-phosphate must be provided via glycolysis with a net cost of four ATP equivalents per molecule. Thus, intracellular storage of one molecule of circulating TAG requires ten ATP. Its subsequent hydrolysis and mobilization has no energetic cost other than a small (catalytic) amount for synthesis and regulation of HSL. This may be compared with the energy yield of complete oxidation of three molecules of fatty acid (e.g. palmitic) of $3 \times 129=387$ ATP. Thus, the energy requirement of white adipose tissue in relation to the amount of energy whose flux it regulates is, as discussed 
Table 2. 'Efficiency' of control of energy flow in different tissues

\begin{tabular}{lccc}
\hline \hline & $\begin{array}{c}\text { Energy flow* } \\
(\mathrm{MJ} / \mathrm{d})\end{array}$ & $\begin{array}{c}\mathrm{O}_{2} \text { consumption } \\
(1 / \mathrm{d})\end{array}$ & $\begin{array}{c}\text { 'Efficiency of } \\
\text { control' } \dagger \\
\left(\mathrm{MJ} \text { handled// } \mathrm{O}_{2}\right)\end{array}$ \\
\hline White adipose tissue & 5 & 6 & 1 \\
Brain & 2 & 66 & 0.03 \\
Resting skeletal muscle & $6(?)$ & 100 & 0.06 \\
\hline
\end{tabular}

* Energy flow represents the total energy throughput in metabolic fuels 'handled' by the tissue per d. It is very approximate. For skeletal muscle it has been taken as the equivalent of the $\mathrm{O}_{2}$ consumption multiplied by 2 to allow for anaerobic glycolysis.

$\dagger$ Efficiency of control is the amount of fuel energy 'handled' per unit $\mathrm{O}_{2}$ consumption (i.e. of irreversible fuel consumption).

earlier, minuscule. White adipose tissue is, indeed, a tissue highly specialized as an efficient regulator of energy flux (Table 2).

\section{CONCLUSION}

Adipose tissue plays a major role (probably the major role) in regulating the flow of lipid substrates in the body. It acts as the long-term reservoir for chemical energy derived from the diet, storing and releasing fatty acids in a highly controlled manner which matches closely the balance between energy intake and energy expenditure in the whole body. In addition, it directs the flow of fatty acids from circulating TAG (especially that in VLDL), which may not even enter its interstitial fluid. It performs these functions with the consumption of a relatively minute amount of fuel. White adipose tissue is clearly an exceptionally efficient participant in the regulation of fuel selection in the body as a whole.

\section{REFERENCES}

Abumrad, N. A., Park, J. H. \& Park, C. R. (1984). Permeation of long-chain fatty acid into adipocytes. Kinetics, specificity, and evidence for involvement of a membrane protein. Journal of Biological Chemistry 259, 8945-8953.

Arner, P., Kriegholm, E., Engfeldt, P. \& Bolinder, J. (1990). Adrenergic regulation of lipolysis in situ at rest and during exercise. Journal of Clinical Investigation 85, 893-898.

Baldo, A., Sniderman, A. D., St-Luce, S., Avramoglu, R. K., Maslowska, M., Hoang, B., Monge, J. C., Bell, A., Mulay, S. \& Cainflone, K. (1993). The adipsin-acylation stimulating protein system and regulation of intracellular triglyceride synthesis. Journal of Clinical Investigation 92, 1543-1547.

Belfrage, P., Fredrikson, G., Olsson, H. \& Strålfors, P. (1985). Molecular mechanisms for hormonal control of adipose tissue lipolysis. International Journal of Obesity 9, Suppl. 1, 129-136.

Bonadonna, R. C., Groop, L. C., Zych, K., Shank, M. \& DeFronzo, R. A. (1990). Dose-dependent effect of insulin on plasma free fatty acid turnover and oxidation in humans. American Journal of Physiology 259, E736-E750.

Boulton, K. L., Hudson, D. U., Coppack, S. W. \& Frayn, K. N. (1992). Steroid hormone interconversions in human adipose tissue in vivo. Metabolism 41, 556-559.

Carlson, M. G., Snead, W. L. \& Campbell, P. J. (1993). Regulation of free fatty acid metabolism by glucagon. Journal of Clinical Endocrinology and Metabolism 77, 11-15.

Carlson, M. G., Snead, W. L., Hill, J. O., Nurjhan, N. \& Campbell, P. J. (1991). Glucose regulation of lipid metabolism in humans. American Journal of Physiology 261, E815-E820. 
Coppack, S. W., Evans, R. D., Fisher, R. M., Frayn, K. N., Gibbons, G. F., Humphreys, S. M., Kirk, M. J., Potts, J. L. \& Hockaday, T. D. R. (1992). Adipose tissue metabolism in obesity: lipase action in vivo before and after a mixed meal. Metabolism 41, 264-272.

Coppack, S. W., Fisher, R. M., Gibbons, G. F., Humphreys, S. M., McDonough, M. J., Potts, J. L. \& Frayn, K. N. (1990a). Postprandial substrate deposition in human forearm and adipose tissues in vivo. Clinical Science 79, 339-348.

Coppack, S. W., Frayn, K. N., Humphreys, S. M., Dhar, H. \& Hockaday, T. D. R. (1989a). Effects of insulin on human adipose tissue metabolism in vivo. Clinical Science 77, 663-670.

Coppack, S. W., Frayn, K. N., Humphreys, S. M., Whyte, P. L. \& Hockaday, T. D. R. (1990b). Arteriovenous differences across human adipose and forearm tissues after overnight fast. Metabolism 39, 384-390.

Coppack, S. W., Frayn, K. N., Whyte, P. L. \& Humphreys, S. M. (1989b). Carbohydrate metabolism in human adipose tissue in vivo. Biochemical Society Transactions 17, 145-146.

Coppack, S. W., Jensen, M. D. \& Miles, J. M. (1994). In vivo regulation of lipolysis in humans. Journal of Lipid Research 35, 177-193.

Coppack, S. W. \& Miles, J. M. (1992). Ketone body metabolism by human adipose tissue. Diabetologia 35, Suppl. 1, A8.

Dawson-Hughes, B., Shipp, C., Sadowski, L. \& Dallal, G. (1987). Bone density of the radius, spine, and hip in relation to percent of ideal body weight in postmenopausal women. Calcified Tissue International 40, 310-314.

Eckel, R. H. (1989). Lipoprotein lipase. A multifunctional enzyme relevant to common metabolic diseases. New England Journal of Medicine 320, 1060-1068.

Edens, N. K., Leibel, R. L. \& Hirsch, J. (1990). Mechanism of free fatty acid re-esterification in human adipocytes in vitro. Journal of Lipid Research 31, 1423-1431.

Elia, M. (1992). Organ and tissue contribution to metabolic rate. In Energy Metabolism: Tissue Determinants and Cellular Corollaries, pp. 61-79 [J. M. Kinney and H. N. Tucker, editors]. New York: Raven Press.

Frayn, K. N. (1992). Studies of human adipose tissue in vivo. In Energy Metabolism: Tissue Determinants and Cellular Corollaries, pp. 267-295 [J. M. Kinney and H. N. Tucker, editors]. New York: Raven Press.

Frayn, K. N. , Coppack, S. W. \& Humphreys, S. M. (1993a). Subcutaneous adipose tissue metabolism studied by local catheterization. International Journal of Obesity 17, Suppl. 3, S18-S21.

Frayn, K. N., Coppack, S. W., Humphreys, S. M., Clark, M. L. \& Evans, R. D. (1993b). Periprandial regulation of lipid metabolism in insulin-treated diabetes mellitus. Metabolism 42, 504-510.

Frayn, K. N., Coppack, S. W., Humphreys, S. M. \& Whyte, P. L. (1989). Metabolic characteristics of human adipose tissue in vivo. Clinical Science 76, 509-516.

Frayn, K. N., Coppack, S. W. \& Potts, J. L. (1992). Effect of diet on human adipose tissue metabolism. Proceedings of the Nutrition Society 51, 409-418.

Frayn, K. N., Coppack, S. W., Walsh, P. E., Butterworth, H. C., Humphreys, S. M. \& Pedrosa, H. C. (1990). Metabolic responses of forearm and adipose tissues to acute ethanol ingestion. Metabolism 39, 958-966.

Frayn, K. N., Khan, K., Coppack, S. W. \& Elia, M. (1991). Amino acid metabolism in human subcutaneous adipose tissue in vivo. Clinical Science 80, 471-474.

Frayn, K. N., Shadid, S., Hamlani, R., Humphreys, S. M., Clark, M. L., Fielding, B. A., Boland, O. \& Coppack, S. W. (1994). Regulation of fatty acid movement in human adipose tissue in the postabsorptiveto-postprandial transition. American Journal of Physiology 266, E308-E317.

Hammond, V. A. \& Johnston, D. G. (1987). Substrate cycling between triglyceride and fatty acid in human adipocytes. Metabolism 36, 308-313.

Harmon, C. M., Luce, P. \& Abumrad, N. A. (1992). Labelling of an $88 \mathrm{kDa}$ adipocyte membrane protein by sulpho-N-succinimidyl long-chain fatty acids: inhibition of fatty acid transport. Biochemical Society Transactions 20, 811-813.

Harper, R. D. \& Saggerson, E. D. (1976). Factors affecting fatty acid oxidation in fat cells isolated from rat white adipose tissue. Journal of Lipid Research 17, 516-526.

Jensen, M. D., Caruso, M., Heiling, V. \& Miles, J. M. (1989). Insulin regulation of lipolysis in nondiabetic and IDDM subjects. Diabetes 38, 1595-1601.

Jensen, M. D., Heiling, V. J. \& Miles, J. M. (1991). Effects of glucagon on free fatty acid metabolism in humans. Journal of Clinical Endocrinology and Metabolism 72, 308-315.

Kowalski, T. J. \& Watford, M. (1994). Production of glutamine and utilization of glutamate by rat subcutaneous adipose tissue in vivo. American Journal of Physiology 266, E151-E154.

Lafontan, M. \& Langin, D. (1995). Cellular aspects of fuel mobilization and selection in white adipocytes. Proceedings of the Nutrition Society 54, 49-63. 
Leboeuf, B. (1965). Regulation of fatty acid esterification in adipose tissue incubated in vitro. In Handbook of Physiology Section 5: Adipose Tissue, pp. 385-391 [A. E. Renold and G. F. Cahill, editors]. Washington, DC: American Physiological Society.

Mårin, P., Rebuffé-Scrive, M., Smith, U. \& Björntorp, P. (1987). Glucose uptake in human adipose tissue. Metabolism 36, 1154-1160.

Napolitano, A., Lowell, B. B., Damm, D., Leibel, R. L., Ravussin, E., Jimerson, D. C., Lesem, M. D., Van Dyke, D. C., Daly, P. A., Chatis, P., White, R. T., Spiegelman, B. M. \& Flier, J. S. (1994). Concentrations of adipsin in blood and rates of adipsin secretion by adipose tissue in humans with normal, elevated and diminished adipose tissue mass. International Journal of Obesity 18, 213-218.

Ong, J. M. \& Kern, P. A. (1989). Effect of feeding and obesity on lipoprotein lipase activity, immunoreactive protein, and messenger RNA levels in human adipose tissue. Journal of Clinical Investigation 84, 305-311.

Pedersen, O., Kahn, C. R. \& Kahn, B. B. (1992). Divergent regulation of the Glut 1 and Glut 4 glucose transporters in isolated adipocytes from Zucker rats. Journal of Clinical Investigation 89, 1964-1973.

Potts, J. L., Fisher, R. M., Humphreys, S. M., Coppack, S. W., Gibbons, G. F. \& Frayn, K. N. (1991). Peripheral triacylglycerol extraction in the fasting and post-prandial states. Clinical Science 81, 621-626.

Richelsen, B. (1992). Release and effects of prostaglandins in adipose tissue. Prostaglandins, Leukotrienes and Essential Fatty Acids 47, 171-182.

Rigden, D. J., Jellyman, A. E., Frayn, K. N. \& Coppack, S. W. (1990). Human adipose tissue glycogen levels and responses to carbohydrate feeding. European Journal of Clinical Nutrition 44, 689-692.

Sadur, C. N. \& Eckel, R. H. (1982). Insulin stimulation of adipose tissue lipoprotein lipase. Use of the euglycemic clamp technique. Journal of Clinical Investigation 69, 1119-1125.

Siiteri, P. K. (1987). Adipose tissue as a source of hormones. American Journal of Clinical Nutrition 45, 277-282.

Snell, K. \& Duff, D. A. (1977). Alanine release by rat adipose tissue in vitro. Biochemical and Biophysical Research Communications 77, 925-932.

Sniderman, A., Baldo, A. \& Cainflone, K. (1992). The potential role of acylation stimulating protein as a determinant of plasma triglyceride clearance and intracellular triglyceride synthesis. Current Opinion in Lipidology 3, 202-207.

Taylor, R., Husband, D. J., Marshall, S. M., Tunbridge, W. M. G. \& Alberti, K. G. M. M. (1984). Adipocyte insulin binding and insulin sensitivity in 'brittle' diabetes. Diabetologia 27, 441-446.

Tischler, M. E. \& Goldberg, A. L. (1980). Leucine degradation and release of glutamine and alanine by adipose tissue. Journal of Biological Chemistry 255, 8074-8081.

Wu, M. S., Jeng, C. Y., Hollenbeck, C. B., Chen, Y.-D. I., Jaspan, J. \& Reaven, G. M. (1990). Does glucagon increase plasma free fatty acid concentration in humans with normal glucose tolerance? Journal of Clinical Endocrinology and Metabolism 70, 410-416. 